\title{
MENINGKATKAN PEMBELAJARAN MATEMATIKA MELALUI PENERAPAN COOPERATIVE LEARNING TIPE STUDENT TEAMS ACHIEVEMENT DIVISION (STAD) KELAS VI-C UPT. SD NEGERI O1 LIMO KAUM
}

\author{
MEILENI \\ meileni01@gmail.com
}

\begin{abstract}
This research was motivated by the low scores in mathematics at VI-C UPT. SD Negeri 01 Limo Kaum. The purpose of this study is to carry out learning that can improve mathematics learning outcomes through the application of cooperative learning type STAD. This research is in the form of PTK (Classroom Action Research) which consists of 2 (two) cycles. After the first cycle is carried out, then reflection is carried out. The results of the reflection carried out in cycle I conclude that it is necessary to carry out cycle II to improve (1) the implementation of learning which includes: learning media, the active role of researchers in helping students, motivation towards students, building cooperation between students and (2) the results of understanding the lesson mathematics After the second cycle was carried out, the results showed that the use of the STAD Cooperative Learning Type Application. has shown very satisfying results. After the second cycle of learning was carried out, the learning process was using the STAD Cooperative Learning Type Application. very effective to improve learning outcomes in mathematics for students of class VI-C UPT. SD Negeri 01 Limo Kaum. Based on the results of data analysis, in this classroom action research, it was found that the results of student tests at the end of the first cycle of action showed an average value of 75.42 with a percentage of $58.3 \%$ absorption. an average of $86.67 \%$ with a percentage of absorption reaching $87.5 \%$. Thus it can be concluded that the application of Cooperative Learning Type STAD., In mathematics lessons can improve student understanding and improve student learning outcomes.
\end{abstract} Keywords: Learning Outcomes, Mathematics and Cooperative Learning Type STAD.

\begin{abstract}
Abstrak: Penelitian ini dilatar belakangi oleh rendahnya nilai pada mata pelajaran matematika di VI-C UPT. SD Negeri 01 Limo Kaum. Tujuan penelitian ini adalah untuk melaksanakan pembelajaran yang dapat meningkatkan hasil belajar matematika melalui Penerapan Cooperative Learning Tipe STAD. Penelitian ini berbentuk PTK (Penelitian Tindakan Kelas) yang terdiri dari 2 ( dua ) siklus. Setelah dilakukan siklus I, kemudian dilakukan refleksi. Hasil refleksi yang dilaksanakan pada siklus I memberikan kesimpulan bahwa perlu dilaksanakan siklus II untuk memperbaiki (1) pelaksanaan pembelajaran yang meliputi: media pembelajaran, peran aktif peneliti dalam membantu siswa, motivasi terhadap siswa, membangun kerjasama antar siswa dan (2) hasil pemahaman terhadap pelajaran matematika Setelah dilaksanakan siklus II, hasil penelitian menunjukkan bahwa penggunaan Penerapan Cooperative Learning Tipe STAD. sudah memperlihatkan hasil yang sangat memuaskan,. Setelah dilaksanakan pembelajaran siklus II,maka pembelajaran dengan Penerapan Cooperative Learning Tipe STAD. sangat efektif untuk meningkatkan hasil belajar dalam pelajaran matematika bagi siswa kelas VI-C UPT. SD Negeri 01 Limo Kaum.

Berdasarkan hasil analisis data, maka dalam penelitian tindakan kelas ini diperoleh gambaran bahwa hasil tes siswa pada akhir tindakan siklus I menunjukkan nilai rata - rata 75,42 dengan persentase daya serap 58,3\% Sedangkan pada tindakan siklus II, siswa yang memperoleh nilai rata - rata $86,67 \%$ dengan persentase daya EISSN 2657-0289 Lembaga Penelitian dan Penerbitan Hasil Penelitian Ensiklopedia $\quad 57$


serap mencapai 87,5\%. Dengan demikian dapat disimpulkan bahwa penerapan pembelajaran Cooperative Learning Tipe STAD., pada pelajaran matematika dapat meningkatkan pemahaman siswa dan meningkatkan hasil belajar siswa.

Kata kunci : Hasil Belajar,Matematika dan Cooperative LearningTipe STAD.

\section{A. Pendahuluan}

Matematika merupakan mata pelajaran yang wajib diikuti oleh siswa baik ditingkat SD, SLTP, bahkan SLTA. Pelajaran ini dinilai juga sangat penting dan sering menjadi perhatian pihak sekolah, hal itu dikarenakan matematika menjadi salah satu mata pelajaran yang masuk dalam ujian nasional. Dalam proses pembelajaran matematika guru banyak mengalami hambatan diantaranya sulit siswa memahami konsep yang diberikan oleh guru, siswa pasif,dan cepat bosan ketika mengikuti pembelajaran. Hal itu berakibat siswa mudah lupa pada materi yang diterimanya dan berujung pada rendahnya hasil belajar siswa. Bahkan dikelas VI siswa telah dikejar berbagai materi yang harus dikuasai sebagai persiapan untuk memasuki UN dan langkah untuk menuju jenjang pendidikan yang lebih tinggi. Di dalam menyampaikan materi guru harus melalui pembaharuan agar materi yang diajarkan dapat menstimulus siswa untuk mencari, melakukan penyelidikan, melakukan pembuktian dan mencari jawaban atas pertanyaan yang ada secara mandiri ataupun berkelompok khususnya mata pelajaran Matematika. Dari observasi yang dilakukan di kelas dalam proses pembelajaran guru hanya mengutamakan kegiatan pembelajaran yang berorientasi pada ranah kognitif, dan sering meninggalkan ranah lain yaitu afektif sehingga perubahan kedewasaan siswa setelah mengikuti rangkaian pembelajaran menjadi kurang maksimal

Trianto (2009: 9) menyatakan proses belajar adalah usaha pendewasaan siswa yang dilakukan dengan membekali siswa dengan berbagai ilmu pengetahuan, keterampilan sehingga dengan pengetahuan dan keterampilan tersebut, siswa dapat sukses menjalani kehidupannya, baik di masa sekarang maupun di masa yang akan datang. Kegiatan belajar yang sesuai dengan perkembangan dan perubahan paradigma pendidikan, adalah kegiatan belajar yang mampu mensinergikan ranah kognitif, afektif,dan psikomotor secara bersamaan, selanjutnya kegiatan belajar tidak hanya menempatkan siswa sebagai objek yang harus mengikuti seluruh keinginan guru, tetapi kegiatan belajar yang mampu mendukung perubahan adalah kegiatan belajar yang membuka dialog dan komunikasi aktif antara siswa dan guru. Trianto (2009: 12) menyatakan kegiatan pembelajaran akan lebih bermakna jika anak mengalami apa yang dipelajarinya, bukan mengetahuinya. Pembelajaran yang berorientasi pada penguasaan materi terbukti berhasil dalam kompetisi mengingat jangka pendek tetapi gagal dalam membekali anak memecahkan persoalan dalam kehidupan jangka panjang, dari hal-hal tersebut peneliti ingin menerapkan di dalam pembelajaran sehingga siswa lebih bermakna dalam menguasai materi

Hal tersebut dapat dilihat dari hasil ulangan harian Matematika yang pertama pada kompetensi dasar mengubah bentuk pecahan ke bentuk desimal hanya mencapai rerata 62,50 dan hanya $37,5 \%$ siswa mencapai nilai KKM atau $>78$. Padahal idealnya minimal harus mencapai $85 \%$ siswa mendapat 78 Sedangkan mengubah bentuk pecahan ke bentuk desimal merupakan dasar bagi kompetensi dasar berikutnya. Kondisi tersebut disebabkan oleh kenyataan sehari-hari yang menunjukkan bahwa siswa kelihatannya jenuh mengikuti pelajaran Matematika. Pembelajaran sehari-hari menggunakan metode ceramah dan latihan-latihan soal secara individual, dan tidak 
ada interaksi antar siswa yang pandai, sedang, dan normal. Hal ini terbukti sebagian besar siswa mengeluh apabila diajak belajar Matematika. Sering jika diberi tugas tidak selesai tepat waktu, dan lebih suka bermain dan mengobrol, alasannya pelajaran Matematika memusingkan dan lain-lain.

Menyikapi kondisi tersebut penulis sebagai guru kelas VI-C UPT. SD Negeri 01 Limo Kaum yang harus menyiapkan peserta didik menuju ujian akhir sekolah dan mampu bersaing dalam mengikuti tes masuk SMP Negeri, selalu berusaha memperbaiki pembelajaran dengan mengkondisikan pembelajaran yang memudahkan, mengasyikkan, dan menyenangkan bagi siswa. Usaha tersebut akan diwujudkan dalam suatu penelitian tindakan kelas yang akan menerapkan pembelajaran Cooperative Learning Tipe Student Teams Achievement Division (STAD).

Berdasarkan uraian di atas, untuk mengetahui ada tidaknya peningkatan hasil belajar belajar pada mata pelajaran Matematika terutama materi mengubah bentuk pecahan ke bentuk decimal, maka dilakukan Penelitian Tindakan Kelas dengan judul" Meningkatkan Pembelajaran Matematika Melalui Penerapan Cooperative Learning Tipe Student Teams Achievement Division (STAD) kelas VI-C UPT. SD Negeri 01 Limo Kaum".

Mengingat keterbatasan yang ada pada peneliti maka tidak semua masalah dibahas dalam penelitian ini. Dalam penelitian ini dibagi menjadi dua point yaitu batasan pendekatan dan batasan materi. Batasan Penerapan Cooperative Learning Tipe Student Teams Achievement Division (STAD) kelas VI Sekolah Dasar. Kelompok yang diteliti dalam penelitian ini berfokus pada siswa kelas VI-C UPT. SD Negeri 01 Limo Kaum. Sedangkan batasan materinya difokuskan pada mengubah bentuk pecahan ke bentuk desimal.

\section{B. Metodologi Penelitian}

Penelitian ini menggunakan metode penelitian tindakan (Action Research). Hal ini sesuai dengan defenisi yang dikemukakan oleh Ebbut (dalam Rochiati, 2007: 12) yang menyatakan "Penelitian tindakan yaitu kajian sistematik dari upaya perbaikan pelaksanaan praktek pendidikan oleh sekelompok guru dengan melakukan tindakan dalam pembelajaran, berdasarkan refleksi mereka mengenai hasil dari tindakan tersebut." Kemmis (2010: 1) mengemukakan bahwa "Penelitian Tindakan merupakan suatu bentuk penelitian reflektif yang dilakukan oleh pelaku dalam masyarakat dan bertujuan untuk memperbaiki pekerjaannya, memahami pekerjaan itu sendiri serta situasi dimana pekerjaaan tersebut dilakukan." Menurut Depdikbud (1999 24) mengungkapkan: Penelitian Tindakan Kelas (PTK) adalah sebagai suatu bentuk kajian yang bersifat reflektif oleh pelaku tindakan, yang dilakukan untuk meningkatkan kemantapan rasional dan tindakan mereka dalam melaksanakan tugas, memperdalam pemahaman terhadap tindakan-tindakan yang dilakukan, serta memperbaiki kondisi dimana praktek-praktek pembelajaran tersebut dilakukan. Penelitian ini dilakukan di kelas VI-C UPT. SD Negeri 01 Limo Kaum Kecamatan Lima Kaum Kabupaten Tanah Datar. Lokasi ini dipilih sebagai tempat penelitian dengan pertimbangan sebagai berikut, pertama, Siswa kurang termotivasi dalam pembelajaran Matematika. Kedua, belum pernah dilaksanakannya pembelajaran dengan model Cooperative Learning Tipe Student Teams Achievement Division (STAD) dalam memgubah bentuk pecahaan ke bentuk desimal di UPT. SD Negeri 01 Limo Kaum Kecamatan Lima Kaum Kabupaten Tanah Datar khususnya di kelas VI-C. Ketiga Peneliti sebagai staf pengajar di sekolah tersebut. Sebagai subjek dalam penelitian ini adalah siswa kelas VI-C di UPT. SD Negeri 01 Limo Kaum Kecamatan Lima Kaum Kabupaten Tanah Datar EISSN 2657-0289 Lembaga Penelitian dan Penerbitan Hasil Penelitian Ensiklopedia $\quad 59$ 
Vol. 3 No.1 April 2021

http://jurnal.ensiklopediaku.org

yaitu sebanyak 24 orang yang teriri dari 8 orang siswa laki-laki dan `16 orang siswa perempuan

\section{Hasil dan Pembahasan \\ Deskripsi Kondisi Awal}

Kondisi awal merupakan kondisi siswa sebelum dilaksanakannya pembelajaran Cooperative Learning Tipe Student Teams Achievement Division (STAD. Sebelum dilakukan tindakan kelas siswa diberi pretes (tes awal) untuk mengetahui tingkat kemampuan pemahaman siswa KD Mengubah bentuk pecahan ke bentuk desimal. Tes dilakukan dengan memberi 10 butir soal. Kemudian dinilai dan diperoleh hasil prosesntase ketuntasan seperti tertuang pada tabel berikut.

Tabel. Hasil Ketuntasan Belajar Siswa Tes Awal (Pra Siklus)

\begin{tabular}{|c|c|c|c|c|c|}
\hline No & Nama Peserta Didik & KKM & Nilai & Tuntas & Belum Tuntas \\
\hline 1 & Afdal & 78 & 30 & & $\sqrt{ }$ \\
\hline 2 & Aira Syifa Istamara & 78 & 60 & & $\sqrt{ }$ \\
\hline 3 & Alif Nazmul Hakim & 78 & 80 & $\sqrt{ }$ & \\
\hline 4 & Ardina Amelia & 78 & 70 & & $\sqrt{ }$ \\
\hline 5 & Dzakiratu Nisa & 78 & 80 & $\sqrt{ }$ & \\
\hline 6 & Dwi Gea Safitri & 78 & 80 & $\sqrt{ }$ & \\
\hline 7 & Fahri Ramadhan & 78 & 60 & & $\sqrt{ }$ \\
\hline 8 & Farel Rahmat Maulana & 78 & 50 & & $\sqrt{ }$ \\
\hline 9 & Fauzi & 78 & 80 & $\sqrt{ }$ & \\
\hline 10 & Ghaniyyah Athaillah & 78 & 70 & & $\sqrt{ }$ \\
\hline 11 & Gusti Ayu & 78 & 50 & & $\sqrt{ }$ \\
\hline 12 & Haikal Nabil & 78 & 40 & & $\sqrt{ }$ \\
\hline 13 & Miftahul Jannah & 78 & 80 & $\sqrt{ }$ & \\
\hline 14 & Muhammad Fathir Adni & 78 & 60 & & $\sqrt{ }$ \\
\hline 15 & Muhammad Royyan Nabawi & 78 & 80 & $\sqrt{ }$ & \\
\hline 16 & Nadzua & 78 & 70 & & $\sqrt{ }$ \\
\hline 17 & Naima Diffany.Dlarina & 78 & 60 & & $\sqrt{ }$ \\
\hline 18 & Naylatul Hikmah & 78 & 80 & $\sqrt{ }$ & \\
\hline 19 & Putih Khumairah & 78 & 80 & $\sqrt{ }$ & \\
\hline 20 & Raditya Ramadhan & 78 & 20 & & $\sqrt{ }$ \\
\hline 21 & Senda Maulana Putra & 78 & 40 & & $\sqrt{ }$ \\
\hline 22 & Sri Adinda & 78 & 90 & $\sqrt{ }$ & \\
\hline 23 & Tiara Arifiana Rahmadani & 78 & 50 & & $\sqrt{ }$ \\
\hline 24 & Nabilla Juliansyah & 78 & 60 & & $\sqrt{ }$ \\
\hline \multicolumn{3}{|c|}{ Jumlah } & 1500 & 9 & 15 \\
\hline \multicolumn{3}{|c|}{ Nilai rata-rata } & 62,50 & & \\
\hline \multicolumn{4}{|c|}{ Persentase. } & $37,5 \%$ & $62.5 \%$ \\
\hline
\end{tabular}

Berdasarkan tabel di atas dapat dilihat bahwa hasil dari tes awal menujukkan bahwa 15 siswa atau $62,5 \%$ dibawah ketuntasan, nilai rata- rata 62,50 dan prosentase ketuntasan hanya $37,5 \%$ atau 9 siswa. Berdasarkan data hasil penelitian pada siklus I mengenai hasil belajar Matematika pokok bahasan Mengubah bentuk pecahan ke bentuk desimal dengan penerapan Cooperative Learning Tipe Student Teams Achievement Division (STAD) dalam proses pembelajaran diperoleh data sebagai berikut: 


\section{Deskripsi Hasil Penelitian Siklus I}

Penelitian dilaksanakan pada kelas VI-C UPT. SD Negeri 01 Limo Kaum. Penelitian dilaksanakan dalam 2 siklus. Masing-masing siklus dilakukan dalam $2 \mathrm{x}$ pertemuan (4 x 35 menit) dengan materi pembelajaran mengubah bentuk pecahan ke bentuk desimal melalui penerapan Cooperative Learning Tipe Student Teams Achievement Division (STAD). Penerapan ini terdiri dari 6 langkah yaitu : (1) penyajian materi, (2) kegiatan belajar kelompok, (3) pemeriksaan terhadap hasil kelompok, (4) pemberian kuis individu, (5) pemeriksaan hasil kuis individu, dan (6) penghargaan terhadap kelompok. Hasil kuis individu yang diperoleh siswa hanya mencapai nilai rata-rata 75,42. Sebagian siswa masih mengalami kesulitan dalam menyelesaikan soal yang diberikan. Pada siklus I masih banyak nilai siswa yang belum mencapai ketuntasan. Data nilai ketuntasan siswa pada siklus 1 .

Berikut tabel rekapitulasi Hasil belajar siswa pada siklus I

Tabel Rekapitulasi Hasil Belajar Peserta Didik Siklus I

\begin{tabular}{|c|c|c|c|c|c|c|}
\hline \multirow{3}{*}{ No } & \multirow{3}{*}{ Nama Peserta Didik } & \multirow{2}{*}{\multicolumn{2}{|c|}{ Siklus I }} & \multirow{2}{*}{ Rata $^{2}$} & \multirow{3}{*}{ Tuntas } & \multirow{3}{*}{$\begin{array}{l}\text { TidakTu } \\
\text { ntas }\end{array}$} \\
\hline & & & & & & \\
\hline & & \multicolumn{2}{|c|}{ Pert 1} & Pert 2 & & \\
\hline 1 & Afdal & 40 & 60 & \begin{tabular}{l|l}
50 \\
\end{tabular} & & $\sqrt{ }$ \\
\hline 2 & Aira Syifa Istamara & 80 & 80 & 80 & $\sqrt{ }$ & \\
\hline 3 & Alif Nazmul Hakim & 80 & 100 & 90 & $\sqrt{ }$ & \\
\hline 4 & Ardina Amelia & 80 & 80 & 80 & $\sqrt{ }$ & \\
\hline 5 & Dzakiratu Nisa & 80 & 100 & 90 & $\sqrt{ }$ & \\
\hline 6 & Dwi Gea Safitri & 80 & 80 & 80 & $\sqrt{ }$ & \\
\hline 7 & Fahri Ramadhan & 60 & 60 & 60 & & $\sqrt{ }$ \\
\hline 8 & Farel Rahmat Maulana & 60 & 80 & 70 & & $\sqrt{ }$ \\
\hline 9 & Fauzi & 80 & 100 & 90 & $\sqrt{ }$ & \\
\hline 10 & Ghaniyyah Athaillah & 80 & 80 & 80 & $\sqrt{ }$ & \\
\hline 11 & Gusti Ayu & 60 & 80 & 70 & & $\sqrt{ }$ \\
\hline 12 & Haikal Nabil & 60 & 60 & 60 & & $\sqrt{ }$ \\
\hline 13 & Miftahul Jannah & 80 & 100 & 90 & $\sqrt{ }$ & \\
\hline 14 & Muhammad Fathir Adni & 60 & 60 & 60 & & $\sqrt{ }$ \\
\hline 15 & $\begin{array}{l}\text { Muhammad Royyan } \\
\text { Nabawi }\end{array}$ & 80 & 80 & 80 & $\sqrt{ }$ & \\
\hline 16 & Nadzua & 80 & 80 & 80 & $\sqrt{ }$ & \\
\hline 17 & Naima Diffany Dlarina & 60 & 60 & 60 & & $\sqrt{ }$ \\
\hline 18 & Naylatul Hikmah & 100 & 100 & 100 & $\sqrt{ }$ & \\
\hline 19 & Putih Khumairah & 80 & 100 & 90 & $\sqrt{ }$ & \\
\hline 20 & Raditya Ramadhan & 40 & 60 & 50 & & $\sqrt{ }$ \\
\hline 21 & Senda Maulana Putra & 40 & 60 & 50 & & $\sqrt{ }$ \\
\hline 22 & Sri Adinda & 100 & 100 & 100 & $\sqrt{ }$ & \\
\hline 23 & Tiara Arifiana Rahmadani & 60 & 80 & 70 & & $\sqrt{ }$ \\
\hline 24 & Nabilla Juliansyah & 80 & 80 & 80 & $\sqrt{ }$ & \\
\hline \multicolumn{2}{|c|}{ Jumlah } & & & 1810 & 14 & 10 \\
\hline \multicolumn{2}{|c|}{ Nilai rata - Rata } & & & 75,42 & & \\
\hline \multicolumn{5}{|c|}{ Pewrsentase Ketuntasan } & $58,3 \%$ & $41,7 \%$ \\
\hline
\end{tabular}

Untuk lebih jelasnya dapat dilihat pada diagram berikut.

\section{Grafik Hasil Belajar Siswa Siklus I}

Berdasarkan hasil analisis data observasi terhadap aktivitas peneliti dan siswa dapat disimpulkan bahwa aktivitas peneliti dan siswa dalam pembelajaran belum 
sesuai dengan yang direncanakan. Hal tersebut disebabkan anatara lain, peneliti masih banyak membantu siswa dalam kerja kelompok dan pada kegiatan awal waktu yang digunakan lebih lama dari pada waktu yang direncanakan.

Untuk memperoleh data tentang pelaksanaan siklus I, dilakukan pengamatan dan tes. Berdasarkan hasil pengamatan diperoleh hal - hal sebagai berikut: 1) Secara umum pembelajaran telah dilakukan sesuai dengan yang direncanakan dan pembelajaran telah mencerminkan penerapan Cooperative Learning Tipe Student Teams Achievement Division (STAD); 2) Dalam melakukan diskusi kelompok, peneliti terlalu aktif memberikan bantuan kepada kelompok. Hal ini disebabkan karena siswa tidak terbiasa belajar dengan membangun sendiri pengetahuannya sehingga siswa banyak bertanya pada peneliti; 3) Pelaksanaan pembelajaran masih belum optimal karena masih ada siswa yang belum memahami materi dengan baik; 4) Peneliti perlu meningkatkan cara memotivasi siswa dalam hal kerjasama serta memberikan bantuan kepada teman yang belum mengerti; 5) Aktivitas siswa selama proses pembelajaran perlu ditingkatkan karena belum semua anggota kelompok berperan aktif dalam kegiatan pembelajaran.

Perbaikan yang harus dilakukan bertolak dari siklus I antara lain: 1) Sebaiknya menggunakan media pembelajaran dari CART yang belum dilengkapi; 2) Mengurangi bantuan kepada siswa agar siswa dapat mengeluarkan ide gagasannya dalam pembelajaran mengubah bentuk pecahan ke bentuk decimal; 3) Memotivasi siswa agar aktif berdiskusi dalam kelompok; dan 4) Diharapkan anggota kelompok yang memiliki kemampuan lebih memberikan motivasi dan perhatian lebih kepada anggota kelompok yang berkemampuan rendah

\section{Deskripsi Hasil penelitian Siklus II}

Penelitian dilaksanakan pada kelas VI-C UPT. SD Negeri 01 Limo Kaum Penelitian dilaksanakan dalam siklus 2 dengan materi pembelajaran menentunkan nilai pecahan dari suatu bilangan pendekatan pembelajaran kerja kelompok. Pendekatan ini terdiri dari 6 langkah yaitu: (1) penyajian materi, (2) kegiatan belajar kelompok, (3) pemeriksaan terhadap hasil kelompok, (4) pemberian kuis individu, (5) pemeriksaan hasil kuis individu, dan (6) penghargaan terhadap kelompok.

Hasil kuis individu yang diperoleh siswa hanya mencapai nilai rata-rata 80,67. Dua siswa masih mengalami kesulitan dalam menyelesaikan soal yang diberikan. Pada siklus II nilai siswa sudah mencapai ketuntasan secara klasikal.

Berikut tabel rekapitulasi Hasil belajar siswa pada siklus II 
Tabel Rekapitulasi Hasil Belajar Siswa Siklus II

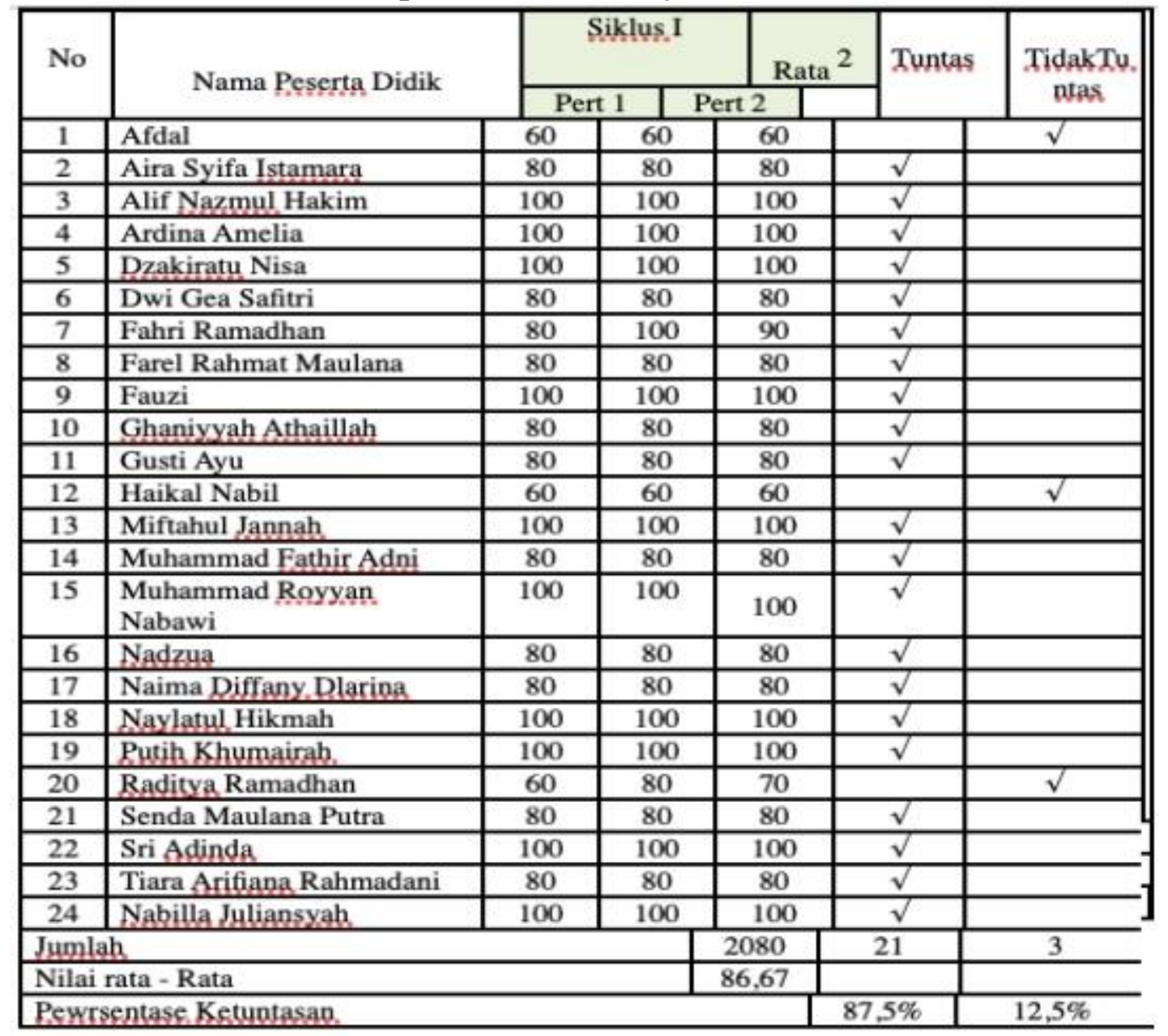

Untuk lebih jelasnya dapat dilihat pada diagram berikut.

\section{Grafik Hasil Belajar Siswa Siklus II}

Berdasarkan analisis hasil observasi terhadap aktivitas peneliti dan siswa dapat disimpulkan bahwa aktivitas peneliti mengajar dan aktivitas siswa belajar sudah sesuai dengan yang direncanakan. Setelah dilakukan evaluasi terhadap hasil observasi dan hasil kuis, dapat dikemukakan hal - hal berikut: 1) Siswa yang berkemampuan rendah telah dibimbing oleh siswa berkemampuan lebih dalam kelompoknya tentang materi nilai pecahan persen dari kuantitas tertentu atau persentase dari sejumlah / besaran tertentu dapat ditentukan dengan diubah lebih dulu ke pecahan biasa; 2) Siswa merasa senang terhadap pembelajaran nilai pecahan persen dari kuantitas tertentu atau persentase dari sejumlah / besaran tertentu dapat ditentukan dengan diubah lebih dulu ke pecahan biasa dengan penerapan Cooperative Learning Tipe Student Teams Achievement Division (STAD); 3) Belum semua subjek penelitian menunjukkan peran aktif dalam diskusi kelompok; dan 4) Kesempatan peneliti dalam memberi bantuan kepada siswa tidak ada lagi. Setiap ada pertanyaan dari siswa, peneliti berusaha untuk mengembalikan pada kelompok. Peneliti meminta siswa untuk mendiskusikannya dengan kelompok sehingga terjalin rasa keberanian dalam mengemungkakan pendapat. Hal ini juga bertujuan untuk melihat respon siswa terhadap pembelajaran nilai pecahan persen dari kuantitas tertentu atau persentase dari sejumlah / besaran tertentu dapat ditentukan dengan diubah lebih dulu ke pecahan biasa dengan penerapan 
Cooperative Learning Tipe Student Teams Achievement Division (STAD). Dengan hasil yang sangat memuaskan maka peneliti mengakhiri pembelajaran nilai pecahan persen dari kuantitas tertentu atau persentase dari sejumlah / besaran tertentu dapat ditentukan dengan diubah lebih dulu ke pecahan biasa sampai siklus II.

\section{Pembahasan}

\section{Pembahasan Tindakan Siklus I}

Tahap Awal. Kegiatan yang dilakukan pada tahap awal ini adalah: (1) Peneliti mengingatkan materi pembelajaran memgubah bentuk pecahaan ke bentuk desimal, (2) Peneliti memotifasi siswa untuk pembelajaran berikutnya. Pembelajaran pada materi tindakan siklus I difokuskan pada materi memgubah bentuk pecahaan ke bentuk desimal. Pembelajaran tindakan siklus I bertujuan untuk memahami mengubah bentuk pecahaan ke bentuk desimal. Dalam tahap awal, ditemukan bahwa ada siswa yang belum mengetahui materi pada pertemuan awal. Hal ini mengakibatkan siswa kesulitan untuk memahami mengubah bentuk pecahaan ke bentuk desimal . Berangkat dari kondisi ini, peneliti memberi bimbingan pada saat kegiatan awal dengan memberikan contoh soal dengan harapan siswa memahami materi berikutnya.

Tahap Inti. Kegiatan yang dilakukan sesuai dengan langkah - langkah pendekatan Kerja kelompok dengan tim, yaitu (1) penyajian materi. (2) mengorganisasikan siswa dalam kelompok dan. (3).pemeriksaan hasil kerja kelompok. Pada tahap penyajian materi, peneliti menggunakan Cart sebagai media pembelajaran. Dalam tahap ini siswa bekerja dalam kelompok yang beranggotakan 5 orang dan ditemukan bahwa siswa belum biasa bekerjasama dengan baik dengan sesama anggota. Belajar kelompok jarang diterapkan dalam kegiatan pembelajaran, akibatnya siswa merasa kesulitan ketika diminta bekerja dalam kelompok. Sering terjadi seorang siswa segan dan malu bertanya. Untuk mengatasi hal tersebut, peneliti meminta semua siswa untuk tidak malu - malu bertanya pada temannya karena penjelasan teman lebih mudah untuk dimengerti. Hasil kerja kelompok diperiksa oleh peneliti secara klasikal. Pada akhir kegiatan, peneliti memberikan kunci jawaban LKPD dan kelompok mencocokan tugasnya dengan kunci jawaban.

Tahap Akhir. Dalam tahap ini, peneliti memberikan soal kuis sebagai bentuk evaluasi atau penilaian. Siswa mengerjakan tes secara individu. Tujuan melakukan kuis/tes akhir adalah untuk melihat hasil belajar. Disamping itu juga untuk menentukan apakah tindakan yang telah dilaksanakan sudah sesuai dengan kriteria yang ditetapkan atau perlu perubahan strategi dalam upaya mencapai tujuan pembelajaran. Siswa yang memperoleh skor diatas KKM siklus I sebanyak 14 siswa dari 24 siswa, sehingga perlu dilakukan tindakan siklus II untuk lebih memantapkan pembelajaran memgubah bentuk pecahaan ke bentuk desimal. Berdasarkan hasil pengamatan pada proses pembelajaran mengubah bentuk pecahaan ke bentuk desimal, peneliti lebih banyak membantu siswa. Hal ini karena siswa baru pertama kali melaksanakan pembelajaran dengan penerapan Cooperative Learning Tipe Student Teams Achievement Division (STAD).dengan tim, sehingga memerlukan waktu dalam kerja kelompok dan membuat rangkuman materi. 


\section{Pembahasan Tindakan Siklus II}

Tahap Awal. Temuan pada tahap ini, siswa sudah memahami materi menentunkan nilai pecahan dari suatu bilangan. Hal ini disebabkan karena peneliti sudah menggunakan Cart yang dilengkapi dengan media pembelajaran.

Tahap Inti. Pembelajaran pada tahap siklus II diawali dengan penyajian materi dengan menyampaikan tujuan pembelajaran, kemudian pemberian lembar kerja kepada masing-masing kelompok. Pada tahap ini siswa sudah dapat menguasai materi menentunkan nilai pecahan dari suatu bilangan. Siswa sudah mulai teliti mengerjakan tugas kelompok dan anggota kelompok sudah mulai aktif dalam kegaiatan kelompok dan saling memberi masukan antara kelompok. Suasana kelas memang agak kurang rapi, tetapi siswa sibuk dengan kegiatan yang sedang dikerjakan. Siswa saling berlomba untuk menyiapkan tugas. Pada saat presentasi siswa membacakan hasil kerja kelompok. Secara umum siswa sudah berani bertanya dan menjawab pertanyaan teman maupun peneliti.

Tahap Akhir. Setelah pembelajaran berakhir, peneliti mengadakan kuis sebagai evaluasi akhir. Tes akhir terdiri dari 5 soal ( terlampir). Hasil tes akhir pada tindakan siklus II ini masih menunjukan subjek yang diteliti tidak mengalami kesulitan dalam menyelesaikan soal. Disamping itu juga untuk menentukan apakah tindakan yang telah dilaksanakan sudah sesuai dengan kriteria yang ditetapkan atau perlu perubahan strategi dalam upaya mencapai tujuan pembelajaran. Siswa yang memperoleh nilai diatas KKM pada siklus II sebanyak 21 siswa dari 24 siswa, sehingga tidak perlu dilakukan tindakan selanjutnya'. Dari tindakan siklus I sampai dengan siklus II terlihat hasil belajar siswa meningkat. perolehan skor siswa pada siklus I yaitu, daya serap 58,3\% , pada siklus II daya serap siswa 87,5\%. Skor terendah adalah 60 dan yang tertinggi adalah 100. Dengan demikian, dapat disimpulkan bahwa pendekatan pembelajaran penerapan Cooperative Learning Tipe Student Teams Achievement Division (STAD).) yang peneliti lakukan ini dapat meningkatkan hasil belajar matematika materi menentunkan nilai pecahan dari suatu bilangan.

\section{Hasil Belajar Siswa Setelah Mengikuti penerapan Cooperative Learning Tipe Student Teams Achievement Division (STAD).}

Hasil belajar siswa merupakan gambaran pemahaman siswa terhadap materi pembelajaran, Pemahaman siswa terhadap materi dikatakan berhasil, jika memenuhi kriteria yang ditetapkan sebelumnya, Hasil belajar siswa dapat diketahui berdasarkan tes disetiap akhir tindakan. Dalam penelitian ini hasil tes siswa pada akhir tidakan siklus I menunjukkan nilai siswa di atas KKM sebanyak 14 orang dengan persentase ketuntasan 58,3\% sedangkan pada tindakan siklus II yang memperoleh diatas KKM sebanyak 21 orang dengan persentase ketuntasan 87,5\%. Dengan melihat hasil tes siswa setelah pelaksanaan tindakan selesai, dapat diartikan penerapan metode Cooperative Learning Tipe Student Teams-Achievement Division (STAD) dalam pembelajaran mengubah bentuk pecahan ke bentuk desimal. dapat meningkatkan pemahaman siswa dan meningkat hasil belajar siswa.

Hasil observasi terhadap penerapan metode Cooperative Learning Tipe Student Teams-Achievement Division (STAD) menunjukkan respon positif. Selain itu, siswa juga mengungkapkan bahwa pelaksanaan pembelajaran secara kelompok dapat memudahkan siswa memahami materi dibandingkan dengan bekerja sendiri. Siswa juga menyadari perlunya menghargai pendapat orang lain karena dapat saling membantu dan terpupuk rasa persatuan dan kebersamaan. Berdasarkan hasil pengamatan juga dapat disimpulkan bahwa siswa dalam mengikuti pembelajaran \begin{tabular}{lll}
\hline EISSN 2657-0289 & Lembaga Penelitian dan Penerbitan Hasil Penelitian Ensiklopedia & 65
\end{tabular} 
mengubah bentuk pecahan ke bentuk desimal dengan penerapan metode Cooperative Learning Tipe Student Teams-Achievement Division (STAD) menjadi termotivasi untuk belajar, karena siswa dapat menerapkan pengetahuan yang diperoleh di sekolah untuk dipergunakan dalam kehidupan nyata siswa.

\section{Penutup}

Dari paparan data dan temuan penelitian dalam bab IV, maka dapat dibuat kesimpulan sebagai berikut: Bentuk pembelajaran dengan melalui penerapan pembelajaran Cooperative Learning Tipe STAD dapat meningkatkan hasil belajar siswa Kelas VI-C UPT. SD Negeri 01 Limo Kau Kecamatan Lima Kaum Kabupaten Tanah Datar terhadap materi mengubah bentuk pecahan ke bentuk desimal Pembelajaran ini menggunakan tiga tahapan yaitu kegiatan awal, kegiatan inti, dan kegiatan akhir. Pada tahap kegiatan awal yang dilaksanakan adalah: (a).Guru mengingatkan materi prasyarat yang dimiliki siswa. (b) Menentukan untuk mengubah pecahan campuran menjadi pecahan decimal. Pada tahap kegiatan inti dilaksanakan: (a) Penyajian materi yaitu menyampaikan tujuan pembelajaran. (b).Melakukan kegiatan kerja kelompok, (c).Pemeriksaan terhadap hasil kerja kelompok. Pada tahap akhir dilaksanakan kegiatan: (a).Pemberian soal kuis secara individu. (b).Pemeriksaan hasil kuis (c).Penghargaan kepada tiap kelompok sesuai dengan kualifikasi Super,Hebat,atau Bagus. Setelah mengikuti pembelajaran dengan penerapan pembelajaran Cooperative Learning Tipe STAD menunjukan hasil yang baik. Hal ini ditunjukan oleh hasil kuis siswa pada akhir siklus I menunjukan nilai rata - rata, 75,42 . Pada siklus II yang memperoleh nilai rata - rata 86,67. Hasil yang diperoleh dalam pembelajaran menentunkan nilai pecahan dari suatu bilangan dengan melalui penerapan pembelajaran Cooperative Learning Tipe STAD ternyata lebih meningkat. Hal ini dapat dilihat dari rata - rata nilai dasar sebelum penerapan pembelajaran Cooperative Learning Tipe STAD yaitu 62,50 sedangkan dengan penerapan pembelajaran Cooperative Learning Tipe STAD dapat memperoleh nilai rata - rata 86,67 .

\section{Daftar Pustaka}

Antonius Cahya Prihandoko. 2006. Pemahamandan Penyajian Konsep Matematika Secara Benar dan Menarik.Departamen Pendidikan Nasional

Depdikbud. (1999). Penelitian Tindakan Kelas. Jakarta : Depdikbud

Eurasia Journal of Mathematics. Science dan Technology Education , 2007.3 (1). 3529

Hernawan, A. H. 2007. Hakikat Strategi Pembelajaran.Bandung: UPI Press

Kemmis \& Mc. Taggart. 2010. The Action Research Planner. Geelong: Deaken Univercity Press.

Ritawati Mahyudin. 2007. Metodologi Penelitian Tindakan Kelas. Padang: UNP Press. Rochiati Wiriaatmadja, 2007. Metode Penelitian TIndakan kelas. Bandung: Remaja Rosdakarya

Suharsimi Arikunto. 2009. Penelitian Tindakan Kelas. Jakarta: Bumi Aksara Isjoni. 2013. Pembelajaran Kooperatif. Jakarta : Rineka Cipta

Isjoni. (2010). Pembelajaran Kooperatif. Meningkatkan kecerdasan antar peserta didik. Yogyakarta : Pustaka Pelajar.

Slavin, E. Robert. 2008. Cooperative Learning Teori Riset dan Praktik. Bandung ; Nusa Media. 
Slavin. 2005. Cooperative Learning. Bandung: Nusa Media

Subarinah,Sri. 2006. Inovasi Pembelajaran Matematika SD. Jakarta: Departemen pendidikan nasional

Susanto, Ahmad. 2013. Teori belajar dan Pembelajaran di Sekolah Dasar. Jakarta: Kencana Perdana Media Group

Tri Wijayanti. 2011. Pengembangan Student Worksheet Berbahasa Inggris SMP Kelas VIII Pada Pembelajaran Aljabar Pokok Bahasan Sistem Persamaan Linear Dua Variabel dengan Pendekatan Pemecahan Masalah Berbasis Kontruktivisme. Universitas Negeri Yogyakarta

Trianto. 2009. Mendisain Model Pembelajaran Inovatif Progresif. Jakarta: Kencana Prenada Group 